\title{
EVALUATION OF THE FAMILY IMPACT SCALE FOR USE IN BRAZIL
}

\author{
Taís de Souza BARBOSA', Maria Beatriz Duarte GAVIÃO²
}

\author{
1- DDS, MSc, Graduate student, Department of Pediatric Dentistry, Pediatric Dentistry Division, Piracicaba Dental School, State University of \\ Campinas, Piracicaba, SP, Brazil. \\ 2- DDS, MSc, PhD, Full Professor, Department of Pediatric Dentistry, Pediatric Dentistry Division, Piracicaba Dental School, State University of
} Campinas, Piracicaba, SP, Brazil.

Corresponding address: Profa. Dra. Maria Beatriz Duarte Gavião - Faculdade de Odontologia de Piracicaba/UNICAMP - Departamento de Odontologia Infantil - Área de Odontopediatria - Avenida Limeira, 901 - 13414-903 - Piracicaba, SP - Brasil - Phone: +55 19 2106 5200/2106 5368 - FAX - +55 19 21065218 - e-mail: mbgaviao@fop.unicamp.br

Received: September 22, 2008 - Modification: May 19, 2009 - Accepted: May 27, 2009

\begin{abstract}
$O$

Objectives: The objectives of this study were to assess the validity and reliability of the Family Impact Scale (FIS) applied in Brazilian parents after translations and cultural adaptations to Brazilian Portuguese language and to evaluate the nature and extent to which the family functioning is compromised by the child oral conditions. Material and Methods: Parents were recruited from general populations for pre-testing $(n=20)$, validity $(n=210)$ and test-retest reliability $(n=20)$ studies. The children were examined for dental caries, gingivitis, fluorosis and malocclusion. Results: The FIS discriminated among the categories of malocclusion and showed good construct validity. The Cronbach's alpha and intraclass correlation coefficients were 0.87 and 0.90 , respectively. Almost $20 \%$ of the informants reported some family impact 'sometimes' or 'often/everyday' from the child's oral condition. Impact on FIS domains of this frequency ranged from $13.8 \%$ for financial difficulties to $24.4 \%$ for parental or family activities. Conclusions: The Brazilian Portuguese version of FIS is valid and reliable. The results suggest that child oral conditions have a negative impact on the family. Further research is required, as these findings were based on cross-sectional study and convenience samples.
\end{abstract}

Key words: Family. Child. Oral health. Quality of life. Validity, Reliability

\section{INTRODUCTION}

The concept of oral health-related quality of life (OHRQoL) relates to the impact which oral health or disease has on the individual's daily functioning, well-being or quality of life (QoL). To date several measures designed to assess OHRQoL have been developed ${ }^{26}$.

There is current interest in children's $\mathrm{QoL}^{18,21}$, which includes social, psychological and functional aspects ${ }^{5}$, as well as oral health ${ }^{5,28}$. In addition, contemporary concepts of child health refer to both the child and the family. The American Academy of Pediatrics defines child health as 'the social, physical and emotional functioning of the child and, when indicated, his or her family'. Therefore, measurement of health-related quality of life must be from the perspective of the child and the family' ${ }^{7}$.

Consequently, the Child Oral Health Quality of Life Questionnaires (COHQoL), a battery of measures that incorporates an assessment of children's own perceptions of the impact of oral health on life quality (Child Perceptions Questionnaires $-\mathrm{CPQ}_{8-10}$ and $\mathrm{CPQ}_{11-14}$ ), primary caregivers/ parents' assessment of the impact of the child's oral health on the life quality of the child (Parental-Caregiver Perceptions Questionnaire - P-CPQ), and primary caregivers/ parents' assessment of the impact of oral health on family life (Family Impact Scale - FIS) were developed ${ }^{12-}$ 14,17 .

There are several motivations for developing a FIS version for use as a component of child health-related QoL measure (e.g. the central role played by the family in child health $)^{24}$ and testing its psychometric properties in a new environment ${ }^{21}$. Translating and adapting a questionnaire developed in one country for use in another usually results in some changes in the wording ${ }^{22}$, which facilitated the development of a culturally relevant instrument, being a strong point of the methodology for using an instrument in a different setting. Preliminary studies have translated, crosscultural adapted and confirmed the validity and reliability of $\mathrm{CPQ}_{8-10}{ }^{2}, \mathrm{CPQ}_{11-14}{ }^{2,8}$ and P-CPQ (T.S. Barbosa, dta nor shown) in Brazil. The psychometric properties of the original FIS version were tested in other countries, such as United Kingdom ${ }^{19}$ and China ${ }^{20}$, but it has not been 
validated for use in Brazil.

The objectives of this study were to assess the validity and reliability of the FIS applied in Brazilian parents after translations and cultural adaptations to Brazilian Portuguese language and to evaluate the nature and extent to which the family functioning is compromised by the child oral conditions.

\section{MATERIAL AND METHODS}

\section{The FIS}

The FIS is included in the P-CPQ and consists of 14 items that attempted to capture the effect of a child's oral or oro-facial condition on four domains related to parental and family activities ( 5 questions), parental emotions (4 questions), family conflict (4 questions) and family finances (1 question) (Figure 1, column 1). The questions were asked about the frequency of events in the previous 3 months. The exact wording of items is: "During the past 3 months, how often... (has there been disagreement or conflict in your family)... because of your child's teeth, lips, mouth or jaws". Response options for the four domains and the respective scores were: 'Never' (scoring 0); 'Once or twice' (1); 'Sometimes' (2); 'Often' (3); and 'Everyday' or 'Almost everyday' (4). A 'Don't know' (DK) response was also allowed. The FIS scores are computed by summing all of the item scores. Scores for each of the four domains can also be computed. Since there were 14 questions, the final score could vary from 0 to 56 , for which a higher score denoted a greater degree of the impact of child's oral conditions on the functioning of parents-caregivers and the family as a whole.

Parents and caregivers were also asked to give overall or global assessments of the child's oral health and the extent to which the oral or oro-facial condition in question affected the child's overall well-being. These global ratings are included in the P-CPQ. The questions are: "How would you rate the health of your child's teeth, lips, jaws and mouth?" with a f5-point response format ranging from 'excellent' to 'poor' and 'How much is your child's overall well-being affected by the condition of his/her teeth, lips, jaws or mouth affect your life overall?" with a response range from 'not at all' to 'very much'. These ratings did not include a DK response.

\section{Translation and Cross-Cultural Adaptation}

The screening process for cross-cultural adaptation was conduct according to Guillemin guidelines ${ }^{10}$. Firstly, two Pediatric Dentists fluent in the English and Brazilian Portuguese languages translated the questions. A conceptual, non-literal translation was emphasized. The first author (TSB) compared the versions, and discussed with translators about the divergences found and a first Brazilian Portuguese version was achieved. Then, two native English speakers, unaware of the objectives of the study, did a back-translation into English. Next, a committee review constituted by three dentist researchers and the first author (TSB) compared source and final versions, solving discrepancies and considering cross-cultural equivalence, thus reaching the second version.

In the pre-testing stage, a convenience sample of 20 parents, recruited from the Department of Pediatric Dentistry (Piracicaba Dental School, State University of Campinas, Brazil), replied to the questionnaire in order to check for errors and deviations in the translations. Furthermore, in each question the alternative "I didn't understand" was added to identify the questions not understood by the parents, i.e. considered culturally inappropriate. The cultural equivalence of the questionnaire was guaranteed when no question with the alternative item had been considered "not applicable" by $15 \%$ or more of the parents.

\section{Validity and Reliability Testing}

All parents of 8- to 14-year-old children from 5 Public Schools of the city Piracicaba, SP, Brazil were invited to participate in this study. Participants were 2.10 pairs of parents and children who fulfilled the inclusion criteria and agreed to participate. The families belonged to a low (C) or very low $(\mathrm{D} / \mathrm{E})$ economic class in accordance with the classification of socioeconomic status of the Associação Brasileira de Empresas de Pesquisa (ABEP) ${ }^{1}$.

The parents were approached through an informative letter, a consent form and the FIS. They were invited to complete the FIS in their home and independently of their children. On the next day, the researcher collected the consent forms and the answered questionnaires from the children at the school. For assessement of test-retest reliability, twenty randomly selected parents were invited to fill out a second copy of the questionnaire two weeks later.

The exclusion criteria were the presence of a systemic or developmental disorders that could compromise the cognitive hability to answer the questions, and children with inappropriate behavior and/or refusal to participate in the evaluation of the variables observed during the clinical examination. Children in need of dental treatment were referred to the Pediatric Dentistry Clinics of Piracicaba Dental School, University of Campinas, Brazil. The study was approved by the Ethics Committee of Piracicaba Dental School (No. 021/2006), University of Campinas, Brazil.

\section{Data collection}

Two calibrated examiners examined the children for dental caries and malocclusion in accordance with World Health Organization criteria ${ }^{29}$. The examinations took place at children's school, out of doors in daylight, but not in direct sunlight. The dmft (sum of decayed, missing and filled teeth in the primary dentition) and DMFT (sum of decayed, missing and filled teeth in the permanent dentition) indices were used to assess caries status. Malocclusion was scored using the Dental Aesthetic Index (DAI) ${ }^{4}$, which assesses the relative social acceptability of dental appearance by collecting and weighting data on 10 intra-oral measurements. This enables each individual to be placed on a dental appearance continuum ranging from 13 (the most socially 


\begin{tabular}{|c|c|c|c|c|c|}
\hline Original version & Brazilian Portuguese version & Respon & options & & \\
\hline $\begin{array}{l}\text { During the past } 3 \text { months, because } \\
\text { of your child's teeth, lips, mouth or } \\
\text { jaws, how often... }\end{array}$ & $\begin{array}{l}\text { Durante os últimos } 3 \text { meses, devido } \\
\text { aos dentes, lábios, boca ou } \\
\text { maxilares do seu filho (a), com que } \\
\text { freqüência: } \\
\text { Atividade dos pais/familiares }\end{array}$ & $\begin{array}{l}\text { Never } \\
\text { Nunca }\end{array}$ & $\begin{array}{l}\text { Once or } \\
\text { twice } \\
\text { Uma/duas } \\
\text { vezes }\end{array}$ & $\begin{array}{l}\text { Sometimes } \\
\text { Algumas } \\
\text { vezes }\end{array}$ & $\begin{array}{l}\text { Often/ } \\
\text { everyday } \\
\text { Freqüen- } \\
\text { temente/ } \\
\text { Todos os dias }\end{array}$ \\
\hline $\begin{array}{l}\text { Have you or the other parent taken } \\
\text { time off work? }\end{array}$ & $\begin{array}{l}\text { Você ou outro membro da família } \\
\text { precisou de dispensa do trabalho (ex. } \\
\text { dor, consultas, cirurgia)? }\end{array}$ & 63.9 & 15.2 & 19.5 & 1.4 \\
\hline $\begin{array}{l}\text { Has your child required more } \\
\text { attention from you or the other } \\
\text { parent? }\end{array}$ & $\begin{array}{l}\text { Seu filho(a) pediu mais sua atenção } \\
\text { ou de outros da família? }\end{array}$ & 61.4 & 12.4 & 19.5 & 6.7 \\
\hline $\begin{array}{l}\text { Have you or the other parent had } \\
\text { less time for yourselves or other } \\
\text { family members? }\end{array}$ & $\begin{array}{l}\text { Você ou outro membro da família } \\
\text { teve menos tempo para si mesmo } \\
\text { ou para família? }\end{array}$ & 49.5 & 12.4 & 26.2 & 11.9 \\
\hline $\begin{array}{l}\text { Has your sleep or that of the other } \\
\text { parent been disrupted? }\end{array}$ & $\begin{array}{l}\text { Você ou outro membro da família } \\
\text { teve o sono interrompido? }\end{array}$ & 61.9 & 8.6 & 21.5 & 8.0 \\
\hline $\begin{array}{l}\text { Have family activities been } \\
\text { interrupted? }\end{array}$ & $\begin{array}{l}\text { Interferiu nas atividades da família } \\
\text { em casa ou em outro lugar? }\end{array}$ & 85.8 & 6.6 & 7.6 & 0.0 \\
\hline Parental emotions & Emoções dos pais & & & & \\
\hline $\begin{array}{l}\text { Have you or the other parent been } \\
\text { upset? }\end{array}$ & $\begin{array}{l}\text { Você ou outro membro da família se } \\
\text { sentiu perturbado? }\end{array}$ & 65.8 & 8.5 & 17.7 & 8.0 \\
\hline $\begin{array}{l}\text { Have you or the other parent felt } \\
\text { guilty? }\end{array}$ & $\begin{array}{l}\text { Você ou outro membro da família se } \\
\text { sentiu culpado? }\end{array}$ & 76.2 & 6.6 & 16.2 & 1.0 \\
\hline $\begin{array}{l}\text { Have your or the other parent } \\
\text { worried that your child will have } \\
\text { fewer life opportunities? }\end{array}$ & $\begin{array}{l}\text { Você ou outro membro da família se } \\
\text { preocupou que seu filho(a) terá } \\
\text { menos oportunidades na vida (ex. } \\
\text { para namorar, casar, ter filhos, } \\
\text { arrumar emprego)? }\end{array}$ & 77.1 & 4.8 & 8.6 & 9.5 \\
\hline $\begin{array}{l}\text { Have you felt uncomfortable in } \\
\text { public places? }\end{array}$ & $\begin{array}{l}\text { Você ou outro membro da família se } \\
\text { sentiu desconfortável em lugares } \\
\text { públicos (ex. lojas, restaurantes) com } \\
\text { seu filho(a)? }\end{array}$ & 85.2 & 6.2 & 7.2 & 1.4 \\
\hline Family conflict & Conflito familiar & & & & \\
\hline $\begin{array}{l}\text { Has your child argued with you or } \\
\text { the other parent? }\end{array}$ & $\begin{array}{l}\text { Seu filho(a) discutiu com você ou } \\
\text { outros da família? }\end{array}$ & 84.3 & 4.3 & 10.4 & 1.0 \\
\hline $\begin{array}{l}\text { Has your child been jealous of you } \\
\text { or other family members? }\end{array}$ & $\begin{array}{l}\text { Seu filho(a) ficou com ciúmes de } \\
\text { você ou de outros membros da } \\
\text { família? }\end{array}$ & 63.3 & 6.7 & 21.9 & 8.1 \\
\hline $\begin{array}{l}\text { Has your child's condition caused } \\
\text { disagreement or conflict in the } \\
\text { family? }\end{array}$ & $\begin{array}{l}\text { Causou discordância ou conflito na } \\
\text { sua família? }\end{array}$ & 70.0 & 11.0 & 15.2 & 3.8 \\
\hline $\begin{array}{l}\text { Has your child blamed you or the } \\
\text { other parent? }\end{array}$ & $\begin{array}{l}\text { Seu filho(a) culpou você ou outra } \\
\text { pessoa da família? }\end{array}$ & 85.7 & 5.3 & 8.0 & 1.0 \\
\hline Financial burden & Dificuldade financeira & & & & \\
\hline $\begin{array}{l}\text { Has your child's condition caused } \\
\text { financial difficulties for your family? }\end{array}$ & $\begin{array}{l}\text { Causou dificuldades financeiras para } \\
\text { sua família? }\end{array}$ & 80.4 & 5.8 & 8.0 & 5.8 \\
\hline
\end{tabular}

FIGURE 1- Distribution (\%) of responses to the family impact items $(n=210)$ 
acceptable) to 100 (the least acceptable), and orthodontic treatment needs can be prioritized based in the pre-defined categories of 'minor/none' (scores 13 to 25), 'definite' (26 to 31 ), 'severe' (32 to 35 ), or 'handicapping' (36 or more) 6 .

Before the dental examination, the examiners underwent a calibration session between them, resulting in interexaminer kappa scores of 0.96 for DMFT/dmft and 0.88 for DAI scores. The intra-examiner reliability was verified by conducting replicate examinations in 20 individuals, a kappa score of 0.95 was obtained for DMFT/dmft and 0.97 for DAI.

\section{Data Analysis}

The resulting data were analyzed with the use of SPSS version 10.1 (SPSS Inc., Chicago, IL, USA). Means and standard deviations were calculated for continuous data, whereas for categorical data the respective frequencies were considered. The zero value was assigned to each "don't know" (DK) response prior to the calculation of scores ${ }^{11}$. Discriminant validity was assessed by comparing overall and domain scores according to the child's age, child's gender and the severity of the child's oral conditions. Since the items were scored using ordinal scale and the most of the distributions were asymmetrical, Mann-Whitney and Kruskal-Wallis nonparametric statistical tests were used (as appropriate) to examine the differences between the means of two categories or three or more categories, respectively. To analyze construct validity, the associations between CPQ scores and the two global indicators were determined, using Spearman's correlation coefficient. Internal consistency was assessed by means of Cronbach's alpha and test-retest reliability by Intra-class Correlation Coefficients (ICCs) calculated by the one-way analysis of variance randomeffects parallel model ${ }^{25}$. The alpha value was set at $\mathrm{p}<0.05$.

\section{RESULTS}

\section{Characteristics of Participants}

No parents/caregivers refused to participate or to complete the questionnaire. A total of 20 parents/caregivers participated in the pre-testing stage and 210 took part in the study to assess validity and internal consistency reliability. Of the latter, 20 provided data for the assessment of testretest reliability. The majority of the informants were the mothers in all three phases (Table 1). A small number of the questionnaires were completed by family members other than parents, such as grandmothers or aunts, for those children living without parents, due to death or abandon.

Table 1 presents the characteristics of the participants in terms of informant, gender, age, and clinical status of the children.

\section{Nature and Extent of Family Impact}

Although data were collected by self-completed questionnaire, there were no missing data. Figure 1 shows the distribution of the responses to the questionnaire. The data indicate that, although one-fifth of parents reported some family impact 'sometimes' or 'often/everyday', for most parents the impacts occurred on an infrequent or sporadic basis. Impact of this frequency on parental or family activities, parental emotions, conflict in the family and financial difficulties was reported by $24.4 \%, 17.3 \%, 17.3 \%$ and $13.8 \%$ of parents, respectively.

\section{Discriminant and Construct Validity}

A clear, but not significant gradient was observed in mean FIS scores across dental caries categories. Concerning malocclusion, there were statistically significant differences in overall and parental emotions scores between those who were in the 'minor' category for malocclusion and the 'severe' and 'handicapping' categories (Table 2).

TABLE 1- Parental informants and children characteristics

\begin{tabular}{|c|c|c|c|c|c|c|}
\hline & \multicolumn{2}{|c|}{ Pre-testing } & \multicolumn{2}{|c|}{ Validity } & \multicolumn{2}{|c|}{ Test-retest reliability } \\
\hline & $\mathbf{n}$ & $\%$ & $\mathrm{n}$ & $\%$ & $\mathbf{n}$ & $\%$ \\
\hline \multicolumn{7}{|l|}{ Informant } \\
\hline Child's mother & 15 & 75.0 & 181 & 86.1 & 19 & 95.0 \\
\hline Child's father & 2 & 10.0 & 21 & 10.0 & 1 & 5.0 \\
\hline Others & 3 & 15.0 & 8 & 3.9 & 0 & 0.0 \\
\hline \multicolumn{7}{|c|}{ Clinical status of children } \\
\hline Dental caries & - & - & 146 & 69.5 & - & - \\
\hline Malocclusion & - & - & 79 & 37.6 & - & - \\
\hline \multicolumn{7}{|l|}{ Gender of child } \\
\hline Boy & 12 & 60.0 & 105 & 50.0 & 13 & 65.0 \\
\hline Girl & 8 & 40.0 & 105 & 50.0 & 7 & 35.0 \\
\hline \multicolumn{7}{|l|}{ Age of child (years) } \\
\hline $8-10$ & 16 & 80.0 & 90 & 42.9 & 10 & 50.0 \\
\hline $11-14$ & 4 & 20.0 & 120 & 57.1 & 10 & 50.0 \\
\hline
\end{tabular}

Adapted from Locker et al. ${ }^{17}$ 


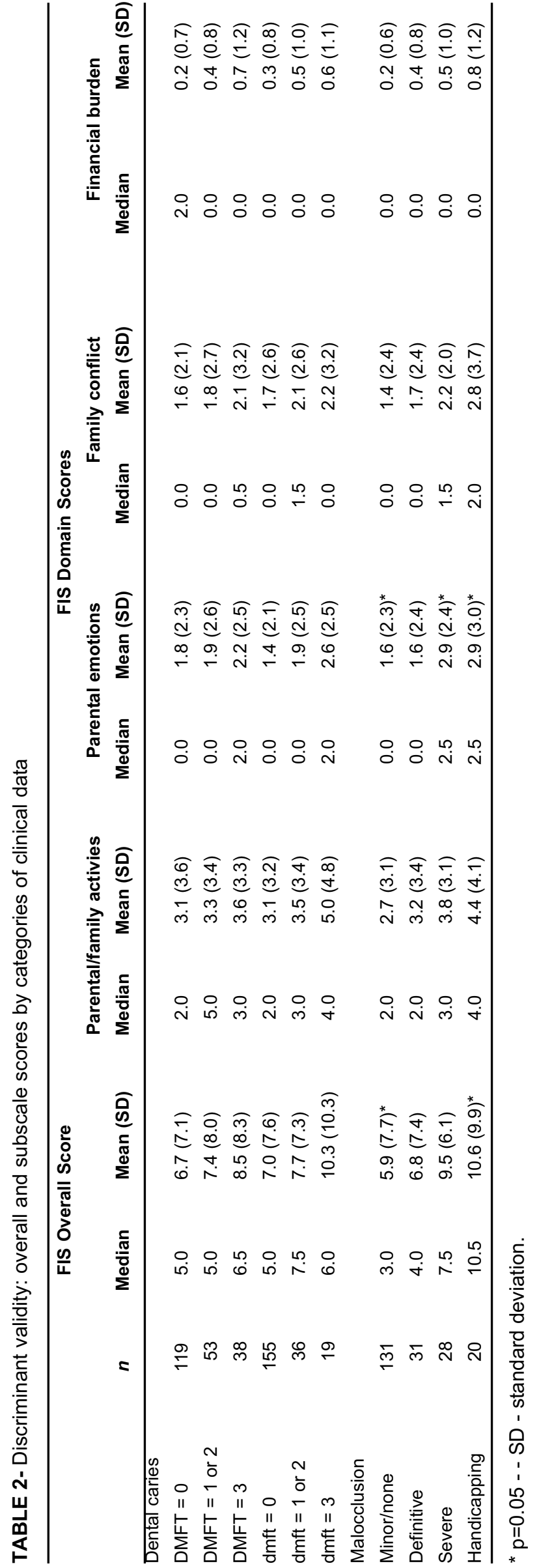

TABLE 3- Construct validity rank correlations between total scale and subscales scores and global rating of oral health and overall well-being $(n=210)$

\begin{tabular}{lcccc}
\hline & \multicolumn{2}{c}{ Oral Health } & \multicolumn{2}{c}{ Overall Well-being } \\
& $\mathbf{R}^{\mathbf{a}}$ & $P$-value & $\mathbf{R}$ & $P$-value \\
\hline $\begin{array}{l}\text { Total scale } \\
\text { Subscales } \\
\text { Oral } \\
\text { symptoms }\end{array}$ & 0.22 & $<0.001$ & 0.30 & $<0.0001$ \\
$\begin{array}{l}\text { Functional } \\
\text { limitations }\end{array}$ & 0.16 & $<0.05$ & 0.27 & $<0.0001$ \\
$\begin{array}{l}\text { Emotional } \\
\text { well-being }\end{array}$ & 0.16 & $<0.05$ & 0.18 & $<0.05$ \\
$\begin{array}{l}\text { Social } \\
\text { well-being }\end{array}$ & 0.16 & $<0.05$ & 0.25 & $<0.001$ \\
\hline
\end{tabular}

a Spearmans correlation coefficient.

In relation to construct validity, there were positive correlations between the parents and caregivers' overall scores and the ratings for oral health $(\mathrm{p}<0.0001)$ and overall well-being $(\mathrm{p}<0.001)$. Positive correlations were also observed between all subscale scores and both global ratings (Table 3).

\section{Internal Consistency and Test-Retest Reliability}

Cronbach's alpha for the overall scale was 0.87 , indicating very high internal consistency reliability. The subscales demonstrated moderate to high internal consistency reliability, as the coefficients ranged from 0.59 to 0.77 (Table 4).

The test-retest reliability was based on data from 20 parents. The ICC for the total scale was 0.90 , indicating perfect agreement, while for the subscales ICCs were 0.87 to 0.91 indicating excellent agreement (Table 4).

\section{DISCUSSION}

In this study, the Brazilian Portuguese version of the FIS was developed, cross-culturally adapted and tested for crosssectional validity and reliability. In pre-testing stage, no problems were encountered, since all parents were able to answer all questions in the questionnaire.

The reliability of the FIS was clearly demonstrated. Internal consistency reliability and test-retest reliability statistics were both excellent, with a Cronbach's alpha and intraclass correlation coefficient of 0.87 and 0.90 , respectively (Table 4). Furthermore, the hypothesis pertaining to construct validity was confirmed. Overall scale scores showed significant associations with parent global ratings of their child's oral health and overall well-being in the direction expected (Table 3 ). These data were consistent with previous findings on validity and reliability study 
TABLE 4- Internal consistency and test-restest reliability of FIS

\begin{tabular}{lcc}
\hline & $\begin{array}{c}\text { Internal consistency } \\
\text { (Cronbach's Alpha) } \\
\boldsymbol{n = 2 1 0}\end{array}$ & $\begin{array}{c}\text { Intraclass correlation } \\
\text { coefficient } \\
\mathbf{( 9 5 \% ~ C l )})^{\mathbf{a}}\end{array}$ \\
\hline Total scale (14 items) & 0.87 & $0.90(0.83-0.93)$ \\
Subscales & & $0.76(0.58-0.84)$ \\
Parent/family activity (5 items) & 0.77 & $0.69(0.51-0.82)$ \\
Parental emotions (4 items) & 0.59 & $0.86(0.70-0.89)$ \\
Family conflict (4 items) & 0.77 & \\
\hline
\end{tabular}

One-way random effect parallel model: ${ }^{a} p<0.001$ for all values.

among Canadian parents ${ }^{17}$, which showed excellent reliability with the internal consistency $(\mathrm{a}=0.83)$ and testretest reliability $(\mathrm{ICC}=0.80)$, and good construct validity.

When testing discriminant validity, a distinct differences in both overall and parent emotion scores across the categories of malocclusion severity was observed, whereby those in the 'Handicapping' category had the highest and those in the 'Minor/none' category had the lowest FIS scores, on average. While there was an apparent difference in the other three domains scores across the categories of malocclusion, it did not quite reach statistical significance (Table 2). Therefore, it was hypothesized that the parents of children with more severe malocclusion are likely (for example) to feel guilty, uncomfortable, worried or upset about the child's condition. However, in a previous study with a Canadian population ${ }^{17}$, malocclusion was considered as much a financial phenomenon as emotional one. These contradictory outcomes can be explained by the fact that different meanings of QoL vary between and within individuals ${ }^{9}$ according to culture and education ${ }^{15}$, contributing for distinct impacts of malocclusion on child QoL, and consequently on the functioning of parents and the family as a whole. These results also support the need to test the psychometric properties of instruments in a new environment ${ }^{23}$.

Analysis within dental caries were not statistically significant, but also provided some evidence to suggest that the FIS scores were associated with the severity of this clinical condition in an expected direction (Table 2). Therefore, studies of the relationship between the oral conditions and the OHRQoL are subject to criticism, as a result of the conceptual distinction between health and disease. Whereas clinical indicators measure disease, OHRQoL indicators concentrate on health and well-being ${ }^{3,16}$. Consequently, although dental caries is relatively prevalent, which is predicted in low income population ${ }^{27}$, in its early stages it may not affect the child's ability to perform his/her family daily activities.

Concerning the nature and extent of family impact resulting from child oral conditions, the present results suggest a negative effect of these conditions on the functioning of parents and the family as a whole (Figure 1).
These data were consistent with Locker et al. ${ }^{17}$ study, which indicated that oral conditions affect parent and family activities, impact on parental emotions and can result in conflict in the family. Thus, these effects are an important source of family distress and should be taken into account when measuring child oral health.

\section{CONCLUSIONS}

In summary, the present study demonstrated that the Brazilian Portuguese version of FIS had good psychometric properties. Moreover, the results suggest that child oral conditions have a negative impact on the family. However, since these findings were based on cross-sectional study and convenience sample, in order to get reliable external validity, the outcomes could address only the descriptive and discriminative potential of FIS and the prevalence estimates and scores apply only to those who took part in the study. This reveals a need for longitudinal studies to assess the evaluative properties of the measure and larger samples recruited from different locations to confirm and extend the findings on family impact reported here.

\section{ACKNOWLEDGEMENTS}

The authors gratefully acknowledge Telma de Souza Barbosa and Carolina Steiner Oliveira for the questionnaire translation. Financial support from CAPES (Coordenação de Aperfeiçoamento de Pessoal de Nível Superior, Brasília, DF, Brazil) is also greatly acknowledged.

\section{REFERENCES}

1- ABEP - Associação Brasileira de Empresas de Pesquisa [Internet].São Paulo: ABEP; c2009 [cited 2009 Jan 18]. Available from: http:// www.abep.org.

2- Barbosa TS, Tureli MC, Gaviao MB. Validity and reliability of the child perceptions questionnaires applied in brazilian children. BMC Oral Health. 2009;9:13. 
3- Bowling A. Research methods in health: investigating health and health services. Buckingham: Open University Press; 1997.

4- Cons NC, Jenny J, Kohout FJ. DAI: the Dental Aesthetic Index. Iowa: Iowa College of Dentistry, University of Iowa; 1986.

5- Eiser C, Morse R. Quality-of-life measures in chronic diseases of childhood. Health Technol Assess. 2001;5:1-157.

6- Estioko LJ, Wright FA, Morgan MV. Orthodontic treatment need of secondary schoolchildren in Heidelberg, Victoria: an epidemiologic study using the Dental Aesthetic Index. Community Dent Health. 1994;11:14751

7- Fink R. Issues and problems in measuring children's health status in community health research. Soc Sci Med. 1989;29(6):715-9.

8- Goursand D, Paiva SM, Zarzar PM, Ramos-Jorge ML, Cornacchia GM, Pordeus IA, et al. Cross-cultural adaptation of the Child Perceptions Questionnaire 11-14 (CPQ11-14) for the Brazilian Portuguese language. Health Qual Life Outcomes. 2008;64:2

9- Gregory J, Gibson B, Robinson PG. Variation and change in the meaning of oral health related quality of life: a 'grounded' systems approach. Soc Sci Med. 2005;60:1859-68.

10- Guillemin F, Bombardier C, Beaton D. Cross-cultural adaptation of health-related quality of life measures: literature review and proposed guidelines. J Clin Epidemiol. 1993;46:1417-32.

11- Jokovic A, Locker D, Stephens M, Guyatt G. Agreement between mothers and children aged 11-14 years in rating child oral health-related quality of life. Community Dent Oral Epidemiol. 2003;31:335-43.

12- Jokovic A, Locker D, Stephens M, Kenny D, Tompson B, Guyatt G. Measuring parental perceptions of child oral health-related quality of life. J Public Health Dent. 2003;63:67-72.

13- Jokovic A, Locker D, Stephens M, Kenny D, Tompson B, Guyatt G Validity and reliability of a questionnaire for measuring child oral-healthrelated quality of life. J Dent Res. 2002;81:459-63.

14- Jokovic A, Locker D, Tompson B, Guyatt G. Questionnaire for measuring oral health-related quality of life in eight- to ten-year-old children. Pediatr Dent. 2004;26:512-8.

15- Krause NM, Jay GM. What do self-rated health items measure? Med Care. 1994;32:930-42

16- Locker D. The burden of oral disorders in a population of older adults Community Dent Health. 1992;9:109-24.

17- Locker D, Jokovic A, Stephens M, Kenny D, Tompson B, Guyatt G. Family impact of child oral and oro-facial conditions. Community Dent Oral Epidemiol. 2002;30:438-48.

18- Mansour ME, Kotagal U, Rose B, Ho M, Brewer D, Roy-Chaudhury A, et al. Health-related quality of life in urban elementary schoolchildren. Pediatrics. 2003;111:1372-81.

19- McGrath C, Pang HN, Lo EC, King NM, Hägg U, Samman N Translation and evaluation of a Chinese version of the Child Oral Healthrelated Quality of Life measure. Int J Paediatr Dent. 2008;18:267-74.

20- Marshman Z, Rodd H, Stem M, Mitchell C, Robinson PG. Evaluation of the Parental Perceptions Questionnaire, a component of the COHQoL, for use in the UK. Community Dent Health. 2007;24:198-204.

21- Meuleners LB, Lee AH, Binns CW, Lower A. Quality of life for adolescents: assessing measurement properties using structural equation modelling. Qual Life Res. 2003;12:283-90.
22- Pires CP, Ferraz MB, de Abreu MH. Translation into Brazilian Portuguese, cultural adaptation and validation of the oral health impact profile (OHIP-49). Braz Oral Res. 2006;20:263-8.

23- Robinson P, Gibson B, Khan F, Birnbaum W. Validity of two oral health-related quality of life measures. Community Dent Oral Epidemiol. 2003;31:90-9.

24- Rothman ML, Hedrick SC, Bulcroft KA, Hickam DH, Rubenstein LZ. The validity of proxy-generated scores as measures of patient health status. Med Care. 1991;29:115-24.

25- Shrout PE, Fleiss JL. Intraclass correlation: uses in assessing rater reliability. Psychol Bull. 1979;86:420-8.

26- Slade GD. Measuring oral health and quality of life. Chapel Hill: University of North Carolina, Dental Ecology; 1997.

27- Tagliaferro EP, Ambrosano GM, Meneghim MC, Pereira AC. Risk indicators and risk predictors of dental caries in schoolchildren. J Appl Oral Sci. 2008;16:408-13

28- Tapsoba H, Deschamps JP, Leclercq MH. Factor analytic study of two questionnaires measuring oral health-related quality of life among children and adults in New Zealand, Germany and Poland. Qual Life Res. 2000;9:559-69

29- World Health Organization. Oral health surveys. Basic methods. Geneva: WHO; 1997. 